\title{
PENGARUH TOUGHT STOPING THERAPY DAN PSIKOEDUKASI KELUARGA TERHADAP TANDA DAN GEJALA PADA KLIEN HIPERTENSI
}

\author{
Mad Zaini \\ Fakultas Ilmu Kesehatan Universitas Muhammadiyah Jember
}

\begin{abstract}
ABSTRAK
Seseorang yang mempunyai pengalaman hipertensi dapat mengalami masalah kesehatan mental. Tujuan dari penelitian ini adalah memaparkan aplikasi tought stoping dan psikoedukasi keluarga pada klien hipertensi. Metode yang digunakan adalah analisis kasus pada klien hipertensi. Jumlah klien yaitu 23 orang. Hasil penelitian menunjukkan bahwa terjadi penurunan tanda dan gejala hipertensi serta peningkatan kemampuan untuk mengontrol hipertensi lebih tinggi pada klien yang mendapatkan dua terapi. Tought stoping dan psikoedukasi keluarga direkomendasikan sebagai intervensi keperawatan pada klien hipertensi.
\end{abstract}

Kata Kunci: Hipertensi, Tought Stoping Terapi, Psikoedukasi Keluarga

\section{ABSTRACT}

Someone who experience hypertension can cause mental health problem. The purpose of research to illustrate the application tought stopping therapy and family psychoeducation in client with hypertension. The method used is the case analisys in client with hypertension. The amount of clients are 23 people. The results were found decrease the signs and symptoms and increase the ability of control hypertension most at clients who get two therapy. Tought stopping therapy and family psychoeducation are recommended a nursing therapy in client with hypertension.

Key words : Hypertension, Tought Stopping Therapy, Family Psychoeducation.

\section{PENDAHULUAN}

Kesehatan jiwa merupakan kondisi yang memungkinkan adanys pcrkembangan fisik, psikologis dan sosial yang optimal dan sesuai dengan kondisi seorang individu (Videback, 2008). Organisasi Kesehatan Dania atau WHO mencarat ada 4 penyakit fisik yang menimbulkan masalah kesehatan jiwa yaitu penyakit kasdievaskeler, diabetes, kanker dan penyakit saluran pernafasan. Penyakit kardiovaskuler salah aatunya adalah hipertensi, Prevalensi hipertensi di Indonesia menunjukkan peningkatan yang signifikan, Peningkatan prevalensi penderita hipertensi disebabkan oleh keterlambatan diagnosa dan belum terjangkaunya pelayanan kesehatan (Depkes RI, 2006).

Pengobatan pada hipertensi terdiri dari 2 jenis tempi, yaitn terapi farmakologj dan nonfarmakologi. Terapi farmakolcgi merupakan bentuk terapi menggunakan obat• obatan antihipertensi sepern beta 
bloker, vasodilator, ACE inhibitor, calcium antagonis dan fain sebagainya, Sedangkan terapi nonfannakclogi merupakan bentuk psikoterapi yang dilakukan pada individu maupun keluarga dengan menekankan pada kemampuan manajemen stress, perubahan gaya hidup serta menghindari rokok dan alkohol (Kaplan, Norman $\mathrm{M}$. 2002).

Aplikasi tindakan keperawatan dari pemberian psikoterapi pada penderjta hipertensi salah satunya adalah terapi penghentikan pikiran (Thought stoptng therapy). Terapi penghentian pikiran adalah teknik terapi yang dapat dilakukan oleh individu setiap kali ingin menghilangkan pikiran negatif serta pikiran yang tidak diinginkan dan penderita Untuk dapat memaksimalkan terapi nonfarmakologi, diperlukan dukungan terutama dari keluarga penderita hipertensi, Dukungan keluarga merupakan salah satn faktor terpenting dalam melakukan perawatan pada penderita hipertensi, Tanpa dukungan keluarga, maka terapi yang dibenkan pada penderita tidak berjalan maksimal (Depkes RI. 2006). Dukungan keluarga pada penderita hipertensi dapat berupa dukungan materi, duknngan emosional dan dukungan nonfinansial.

Untuk dapat memberikan dukungan dengan benar, kelaurga perlu pengetahuan tentang hipertensi serta ketrampilan dalam merawatnya. Psikoedukasi keluarga merupakan salah satu metode yang berdasarkan penelitian klinis dan berguna untuk melatih dan membantu kelaurga dalam meningkatkan pengetahuan serta ketrampilan melalui pemberian informasi, pemberian dukungan, melatih keluarga merawat klign serta melatih manajemen beban keluarga.

Hasil penelitian sebelumnya tentang psikoedukasi keluarga menunjnkkan bahwa psikoedukasi keluarga dapat meningkatkan dukungan keluarga dalam meningkatkan kepatuhan minum obat pada klien (Widyastuti, N., Daulima, N.HC., dan Mustiksasri. 2014). Kombinasi tindakan keperawatan generalis dan psikoedukasi keluarga dipilih peneliti untuk meningkatkan kemampuan keluarga dengan alasan paket terapi tersebut sesuai dengan karakteristik masalah yang sering dialami oleh kelaurga dalam merawat klien hipertensi, seperti kesulitan dalam mengenali penyebab, tanda gejala hipertensi, serta hambatan dalam melakukan manajemen dan pemberdayaan keluarga.

Penelitian yang berfokus keluarga dan terapi nonfarmakologi sarnpai dengan saat ini masih belum banyak dipublikasikan serta pengalaman klinis menunjukkan bahwa kombinasi tindakan keperawatan pada keluarga juga belum banyak dilakukan, dengan demikian peneliti tertarikuntuk mengidentifikasi sejauh mana pengaruh tindakan thought stoptng therapy dan psikoedukasi keluarga terhadap tanda dan gejala klien hipertensi. 


\section{METODE PENELITIAN}

Desain penelitian ini adalah dengan melakukan analisis kasus pada 23 klien dengan hipertensi, sebelum dilakukan tindakan keperawatan generalis pada klien dan psikoedukasi pada keluarga, sebanyak 23 klien dinilai tanda dan gejala yang muncul mulai dari gejala kognitif, afektif, fisiologis, perilaku dan sosial. Kemudian hasil akhirnya dibandingkan dengan tanda dan gejala setelah diberikan tindakan thought stoptng therapy dan psikoedukasi pada keluarga.

\section{HASIL}

Tindakan keperawatan berupa thought stoptng therapy dan psikoedukasi dilakukan pada saat melakukan home visit. langkahlangkah tindakan yaitu mengidentifikasi pikiran negatif kemudian melatih menghentikan pikiran negatif yang muncul dengan hitungan dan alarm. Klien dilatih untuk mengidentifikasi pikiran yang mengganggu kemudian perawat mendemonstrasikannya. Selanjutnya klien diminta mendemosntrasikan kembali seperti yang perawat lakukan. Langkah selanjutnya perawat melakukan evaluasi manfaat dari latihan thought stoptng therapy yang klien lakukan. Psikoedukasi pada keluarga dilakukan bersamaan dengan evaluasi thought stoptng therapy. Terapi psikoedukasi dilakukan dalam 5 sesi.

Berikut ini hasil dari thought stoptng therapy dan psikoedukasi yang dilakukan pada klien hipertensi.
Tabel 1

Pengaruh thought stoptng therapy dan psikoedukasi keluarga terhadap tanda dan gejala klien hipertensi

\begin{tabular}{lllc}
\hline No & $\begin{array}{c}\text { Tanda dan } \\
\text { gejala }\end{array}$ & $\begin{array}{c}\text { Terapi } \\
\text { penghentian } \\
\text { pikiran dan } \\
\text { psikoedukasi } \\
\text { keluarga }\end{array}$ \\
\hline & Kognitif & Pre & Post \\
\hline 1 & $\begin{array}{l}\text { Menyadari gejala } \\
\text { fisiologis }\end{array}$ & 12 & 5 \\
\hline 2 & $\begin{array}{l}\text { Fokus pada hal } \\
\text { yang sakit }\end{array}$ & 19 & 7 \\
\hline 3 & $\begin{array}{l}\text { Sulit mengambil } \\
\text { keputusan }\end{array}$ & 7 & 0 \\
\hline 4 & Sulit konsentrasi & 4 & 1 \\
\hline $\begin{array}{l}\text { Rata-rata tanda } \\
\text { gejala yang dialami }\end{array}$ & $\mathbf{1}$ & $\mathbf{0 , 5}$ \\
\hline
\end{tabular}

\begin{tabular}{llll}
\hline \multicolumn{2}{l}{ Afektif } & & \\
\hline 1 & Khawatir & 15 & 3 \\
\hline 2 & Bingung & 15 & 4 \\
\hline 3 & $\begin{array}{l}\text { Cenderung } \\
\text { menyalahkan } \\
\text { orang lain }\end{array}$ & 8 & 0 \\
\hline 4 & $\begin{array}{l}\text { Tidak percaya } \\
\text { diri }\end{array}$ & 5 & 2 \\
\hline 5 & Sedih & 0 \\
\hline $\begin{array}{l}\text { Rata-rata tanda } \\
\text { gejala yang dialami }\end{array}$ & $\mathbf{2}$ & $\mathbf{1}$ \\
\hline & Fisiologis & \\
\hline 1 & Tanda-tanda vital & 14 & 3 \\
\hline
\end{tabular}




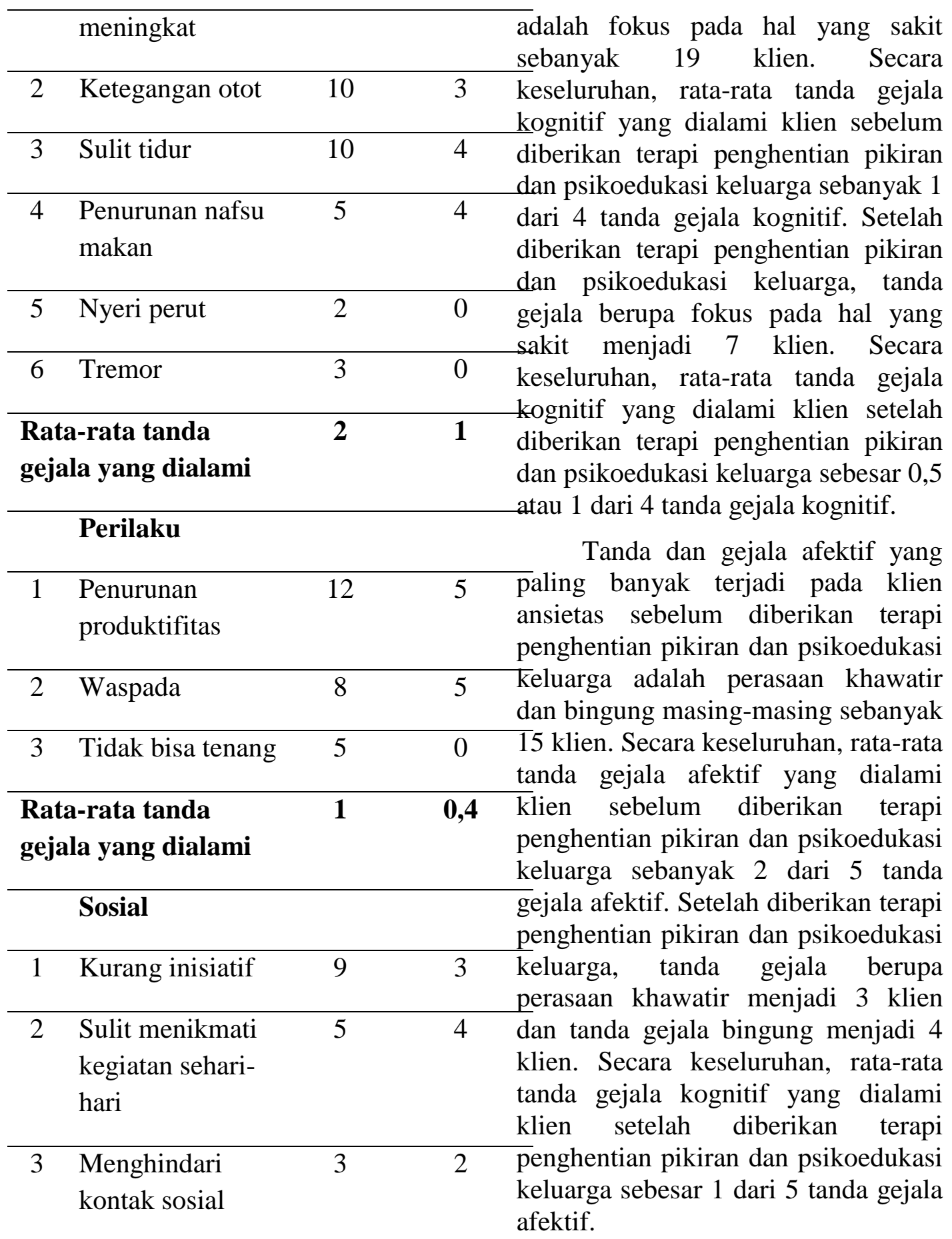

\begin{tabular}{lll}
\hline $\begin{array}{l}\text { Rata-rata tanda } \\
\text { gejala yang dialami }\end{array}$ & 1 & $\mathbf{0 , 3}$
\end{tabular}

Tanda dan gejala fisiologis yang paling banyak terjadi pada klien ansietas sebelum diberikan terapi penghentian pikiran dan psikoedukasi

Berdasarkan tabel diatas tanda dan gejala kognitif yang paling banyak terjadi pada klien ansietas sebelum diberikan terapi penghentian pikiran dan psikoedukasi keluarga keluarga adalah peningkatan tandatanda vital sebanyak 14 klien. Secara keseluruhan, rata-rata tanda gejala fisiologis yang dialami klien sebelum diberikan terapi penghentian pikiran 
dan psikoedukasi keluarga sebanyak 2 dari 6 tanda gejala fisiologis. Setelah diberikan terapi penghentian pikiran dan psikoedukasi keluarga, tanda gejala berupa peningkatan tandatanda vital menjadi 3 klien. Secara keseluruhan, rata-rata tanda gejala fisiologis yang dialami klien setelah diberikan terapi penghentian pikiran dan psikoedukasi keluarga sebesar 0,6 atau 1 dari 6 tanda gejala fisiologis.

Tanda dan gejala perilaku yang paling banyak terjadi pada klien ansietas sebelum diberikan terapi penghentian pikiran dan psikoedukasi keluarga adalah penurunan produktifitas sebanyak 12 klien. Secara keseluruhan, rata-rata tanda gejala perilaku yang dialami klien sebelum diberikan terapi penghentian pikiran dan psikoedukasi keluarga sebanyak 1 dari 3 tanda gejala perilaku. Setelah diberikan terapi penghentian pikiran dan psikoedukasi keluarga, tanda gejala penurunan peoduktifitas menjadi 5 klien. Secara keseluruhan, rata-rata tanda gejala perilaku yang dialami klien setelah diberikan terapi penghentian pikiran dan psikoedukasi keluarga sebesar 0,4 dari 3 tanda gejala perilaku.

Tanda dan gejala sosial yang paling banyak terjadi pada klien ansietas sebelum diberikan terapi penghentian pikiran dan psikoedukasi keluarga adalah kurang inisiatif sebanyak 9 klien. Secara keseluruhan, rata-rata tanda gejala sosial yang dialami klien sebelum diberikan terapi penghentian pikiran dan psikoedukasi keluarga sebanyak 1 dari 3 tanda gejala sosial. Setelah diberikan terapi penghentian pikiran dan psikoedukasi keluarga, tanda gejala berupa kurang inisiatif menjadi 3 klien. Secara keseluruhan, rata-rata tanda gejala sosial yang dialami klien setelah diberikan terapi penghentian pikiran dan psikoedukasi keluarga sebesar 0,3 dari 3 tanda gejala sosial.

\section{PEMBAHASAN}

Tanda dan gejala kognitif yang paling banyak sebelum diberikan terapi penghentian pikiran dan psikoedukasi keluarga adalah fokus pada hal yang sakit sebanyak 19 klien. secara keseluruhan, rata-rata tanda gejala kognitif sebanyak 1 tanda gejala kognitif yang dialami oleh klien sebelum diberikan tindakan keperawatan. klien dengan masalah kesehatan fisik menimbulkan perubahan konsentrasi dan fokus pemikiran kepada hal yang sakit, kondisi seperti ini diperberat juga dengan adanya koping yang maladaptif sehingga akan berpengaruh pada kognitif klien (Kaplan, Norman M. 2002).

Perubahan tanda dan gejala kognitif setelah diberikan thought stoptng therapy dan psikoedukasi keluarga, tanda gejala tersebut berkurang menjadi 7 klien. secara keseluruhan rata-rata gejala kognitif sebanyak 1 dari 4 tanda gejala kognitif sebelum diberikan terapi. hasil ini sejalan dengan penelitian sebelumnya, bahwa terapi penghentian pikiran mampu menurunkan tanda gejala ansietas pada klien masalah kesehatan fisik (Agustarika, B. Keliat, B.A \& Susanti, Y. 2009). hasil penelitian ini membuktikan bahwa terapi penghentian pikiran dan psikoedukasi keluarga mampu menurunkan tanda gejala dan meningkatkan kemampuan keluarga (care giver).

Tanda dan gejala afektif yang paling banyak terjadi pada klien 
sebelum diberikan terapi penghentian pikiran dan psikoedukasi kelaurga adalah perasaan khawatir sebanyak 15 klien. secara keseluruhan, rata-rata tanda gejala afektif sebelum diberikan tindakan keperawatan sebanyak 2 dari 5 gejala afektif. perasaan cemas sebagai bagian dari respon klien terhadap adanya stressor baik fisik maupun psikologis (Sauceda. M, 2011). kondisi ansietas yang tidak segera ditangani mengakibatkan ketegangan dalam hidup dan menyebabkan klien menjadi waspada dan perubahan perilaku yang mengarah pada perilaku maladaptif. setelah diberikan terapi penghentian pikiran dan psikoedukasi keluarga, tanda gejala berupa perasaan khawatir menjadi 3 klien. secara keseluruhan, rata-rata tanda gejala afektif sebanyak 1 dari 5 gejala afektif setelah diberika terapi penghentian pikiran dan psikoedukasi keluarga. penelitian ini menunjukkan bahwa tought stoping therapy dan psikoedukasi keluarga mempengaruhi tanda gejala afektif pada klien.

Tanda dan gejala fisiologis yang paling banyak terjadi pada klien sebelum diberikan terapi penghentian pikiran dan psikoedukasi kelaurga adalah peningkatan tanda-tanda vital sebanyak 14 klien. secara keseluruhan, rata-rata tanda gejala fisiologis sebanyak 2 dari 6 tanda gejala fisiologis yang dialami klien. setelah diberikan terapi penghentian pikiran dan psikoedukasi kelaurga, tanda gejala tersebut terjadi pada 3 klien, yang secara keseluruhan ratarata tanda gejala fisiologis yang masih ada sebesar 0,6 atau 1 dari 6 tanda gejala fisiologis. Peneliti berpendapat bahwa penurunan tandatanda vital pada klien hipertens lebih banyak karena adanya dukungan dari keluarga dalam merawat klien. kemampuan keluarga dalam memberikan perawatan pada klien, termasuk mengingatkan minum obat serta kontrol kesehatan secara rutin ke pelayanan kesehatan sangat bermanfaat dalam menurunkan tanda dan gejala fisiologis.

Tanda dan gejala perilaku yang paling banyak terjadi pada klien sebelum diberikan terapi penghentian pikiran dan psikoedukasi keluarga adalah penurunan produktifitas sebanyak 12 klien. secara keseluruhan, rata-rata gejala perilaku sebelum diberikan terapi penghentian pikiran dan psikoedukasi keluarga sebanyak 1 dari 3 tanda gejala perilaku. penurunan produktifitas pada klien hipertensi lebih banyak disebabkan oleh adanya peningkatan tekanan darah yang cenderung membatasi klien untuk beraktifitas termasuk aktifitas sehari-hari di rumah (Sarafino, 2006). setelah diberikan terapi penghentian pikiran dan psikoedukasi keluarga, tanda gejala penurunan produktifitas menjadi 5 klien. secara keseluruhan, rata-rata tanda gejala perilaku sebesar 0,4 setelah diberikan terapi penghentian pikiran dan psikoedukasi keluarga. dukungan keluarga akan semakin menguatkan koping klien dalam menghadapi stressor. dukungan keluarga akan membantu klien mencapai koping adapatif dalam menghadapi stressor (Ponce et al, 2011). penulis berpendapat bahwa koping yang adaptif dalam menghadapi stressor akan berpengaruh terhadap perilaku klien terutama pada saat klien menghadapi stressor berupa masalah kesehatan. hasil ini memberikan kesimpulan bahwa secara keseluruhan, rata-rata tanda gejala perilaku menjadi berkurang setelah diberikan terapi 
penghentian pikiran dan psikoedukasi keluarga.

Tanda dan gejala sosial yang paling banyak terjadi pada klien sebelum diberikan terapi penghentian pikiran dan psikoedukasi kelaurga adalah kurang inisiatif sebanyak 9 klien. secara keseluruhan, rata-rata gejala sosial sebelum diberikan terapi penghentian pikiran dan psikoedukasi keluarga sebanyak 1 dari 3 tanda gejala sosial. tanda gejala kurang inisiatif tersebut terjadi sebagai akibat dari adanya stressor baik fisik, psikologis maupun stressor sosial. setelah diberikan terapi penghentian pikiran dan psikoedukasi keluarga, tanda gejala berupa kurang inisiatif menurun menjadi 3 klien dengan kseluruhan rata-rata gejala sosial sebesar 0,3 dari 3 tanda gejala sosial. hasil ini menunjukkan bahwa terapi penghentian pikiran dan psikoedukasi keluarga mampu menurunkan ratarata gejala sosial klien.

\section{SIMPULAN}

Tought stoping therapy dan psikoedukasi keluarga berpengaruh terhadap penurunan tanda dan gejala kognitif, afektif, fisiologis, perilaku dan sosial yang dialami klien hipertensi serta meningkatkan kemampuan klien dalam mengendalikan masalah kesehatannya.

\section{SARAN}

Pelayanan kesehatan terutama keperawatan di pusat pelayanan kesehatan di masyarakat diharapkan dapat mengaplikasikan pelayanan holistic pada unit pelayanan kesehatan perorangan maupun unit pelayanan keluarga atau masyarakat. bagi klien atau masyarakat dengan masalah kesehatan hipertensi diharapkan mampu menerapkan ketrampilan yang sudah diberikan dalam rangka mengontrol serta mengendalikan tanda gejala yang muncul.

\section{DAFTAR PUSTAKA}

Agustarika, B. Keliat, B.A \& Susanti, Y. (2009). pengaruh terapi thought stoping terhadap ansietas klien dengan gangguan fisik di rsud kabupaten sorong. tesis. tidak dipublikasikan.

Depkes RI. (2006). pedoman kegiatan perawat kesehatan masyarakat di puskesmas. jakarta: direktorat bina pelayanan keperawatan

Kaplan, norman m. (2002). kaplan's clinical hypertension. $8^{\text {th }} \mathrm{ed}$. philadelphia: lippincott williams \& wilkins

Keliat, B.A. (2007). modul ic-cmhn. fakultas ilmu keperawatan universitas indonesia

Kozier at al. (2007). fundamental nursing: concepts, process, and practice. eight edition. new jersey: pearson education, inc

Ponce. c. Costa, Ordonez n. Tiago, Silva B.L Thais. (2011). effects of a psychoeducational intervention in family caregivers of people with alzheimer's disease. dement neuopsychol 2011 september, 5(3).226-237.

http://www.demneuropsy.com .br/imagebank/pdf/v5n3a11.pd $\mathrm{f}$

Sarafino, E.P. (2006). health psychology : biopsychosocial 
interactions. fifth edition.usa : john wiley \& sons.

Sauceda. M, (2011), family psychoeducation for latino populations with mental illness living in the united states. university of medicine and dentistry of new jersey critical literature review and scientific writing-idst 6400 